\title{
Design of Cost Effective Independent Power System Using Renewables for Rural Villages
}

\author{
A.Ramakrishna ${ }^{1}$, V.Sharatbabu, R.Bhaskar ${ }^{3}$,N.Srinivas ${ }^{4}$, K.Venkateswarlu ${ }^{5}$ \\ 1, 2, 3, 4, 5 Electrical \& Electronics Engineering department, Vardhaman college of Engineering, India.
}

\begin{abstract}
Independent power systems (IPS) consist of a solution for the electrification of applications when the access to a large transmission network is not reasonably viable or even unfeasible. Their size can range from few hundred Watts to tens or hundreds of MW.This paper discusses the economic analysis of integrating a solar, wind, battery storage systems into diesel-electric power systems for remote villages, in which the cost of electricity supplied is reduced with the help of different combinations of PV cells, wind with diesel, battery system. The economic part of the model calculates the fuel consumed, the kilo watt hours obtained per litre of fuel supplied, and the total cost of fuel, savings due to PV, wind and battery system. The above concept is studied for six different cases and their corresponding models are designed with the help of Matlab/Simulink Software
\end{abstract}

Keywords:- Independent power system, Renewable energy sources, PV cells, wind power, Simulink

\section{INTRODUCTION}

Energy is essential to human being and it generates economic development. While in most western countries electrical energy is seen as a common commodity, in many other countries people have scarcely access to a sustainable power source for electricity. According to the International Energy Agency an estimated 1.3 billion people in the world are without access to electricity. Furthermore, over 2.7 billion people are without clean cooking facilities.

If present policies do not change, the International Energy Agency predicts there will still be 1.2 billion people who have no access to electricity by the year 2030. As described above, the role of electrical energy is essential for development. Access to energy reduces hunger and improves access to fresh drinking water through the ability of preserving food and pumping clean water via a pumping system.

Rural areas in developing and developed countries, without the necessary grid infrastructure, are a characteristic example of applications with a high potential for the development of Independent Power System (IPS). Taking into account the strong association between the economic development in these areas and their electrification, the importance of powering them is obvious. Other application fields include houses, physical islands and remote telecommunication and industrial installations.

IPSs can be based on renewable energy sources (RES), such as solar, wind, battery storage and fossil fuel generators. Due to the intermittent nature of renewable energy, storage devices and appropriate demand management strategies are necessary when conventional generators are not included in the system In the case of IPS electrified by fossil-fuel units, Diesel Generator (DG) is usually utilised, due to their low cost and reliability. However, the fuel used is polluting and expensive taking into account the transportation costs. A solution to these problems can be the introduction of RES in the energy merge, when ample resources are available. In such a case considerable improvement can be accomplished in terms of fuel saving.

However, for the achievement of a large diffusion of renewable sources technical issues related to system stability and reliability of supply, due to the fluctuating and intermittent characteristics of RES must be confronted, to overcome this can be achieved through the introduction of controllable storage devices and demand-management techniques[1].

The input data to the model are acquired using a remote terminal unit (RTU). The RTU allows for remote data collection and system control while also providing information necessary for modelling the APS. In this paper a model is proposed to process the information obtain from RTU to optimize the performance of the APS.This paper presents a model based on an IPS in which different combinations of its input sources are preferred for the economic generation of electricity. Using Simulink, other renewable energy sources, dynamic operation, and control system strategies can be easily incorporated into the existing IPS model to study the overall performance of the system.

\section{INDEPENDENT POWER SYSTEM MODEL}

Electrical energy is a crucial constraint for economic and of essential substance in societal and industrial development. The ample energy available in nature can be harnessed and converted to electricity in a 
sustainable way to supply the necessary power to raise the living standards of the people without access to the electricity grid.

In general, when two or more different sources of electricity are connected to a common grid and hand in hand to supply the desired load, the system becomes an IPS [2]. A simple model diagram of an IPS is shown in Fig.1. The sources of electric power in this system consist of a diesel generator, a battery bank, wind turbine, and a PV array. The diesel generator is the main source of power for many of the remote villages around the world. The output of the diesel generator is regulated ac voltage, which supplies the load directly through the main distribution transformer. The battery banks, wind turbine and the PV array, are interlinked through a dc bus.

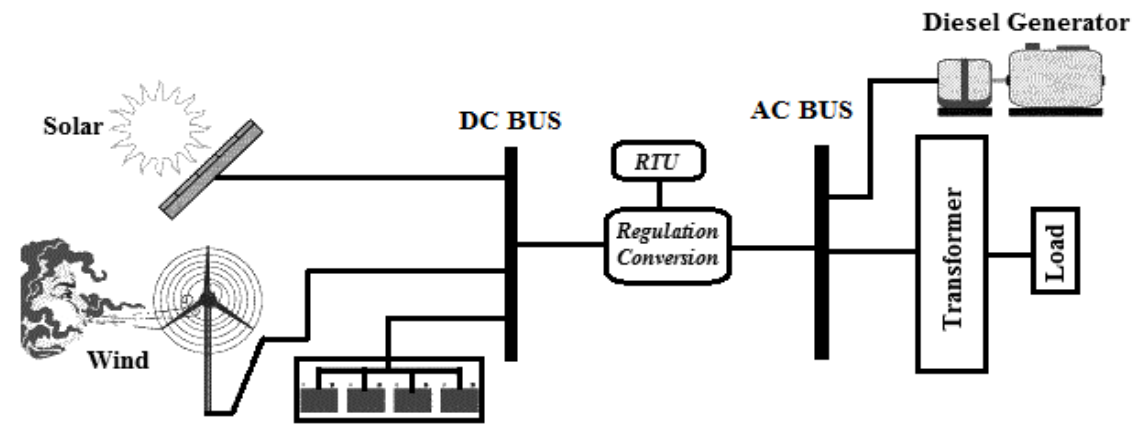

Battery Bank

Fig.1. Independent Power System Model

RTU is control block which control the flow of power by switching between different input units based on the load need to be supplied. As we can see in the block diagram of autonomous energy power system the different energy sources such as PV cells, wind turbine connected to the centralized DC bus and even battery bank is also connected to the same bus. Diesel generator is separately connected to AC bus and all these units are again connected to the RTU. Now based on the load, RTU sends signal to the different units to supply load. If the demand is more RTU activates the other sources (Solar, Wind and Battery bank) to meet the maximum power demand.

III. MODELLING OF INDEPENDENT POWER SYSTEM

In this paper the following load curve is considered for six different cases as follows

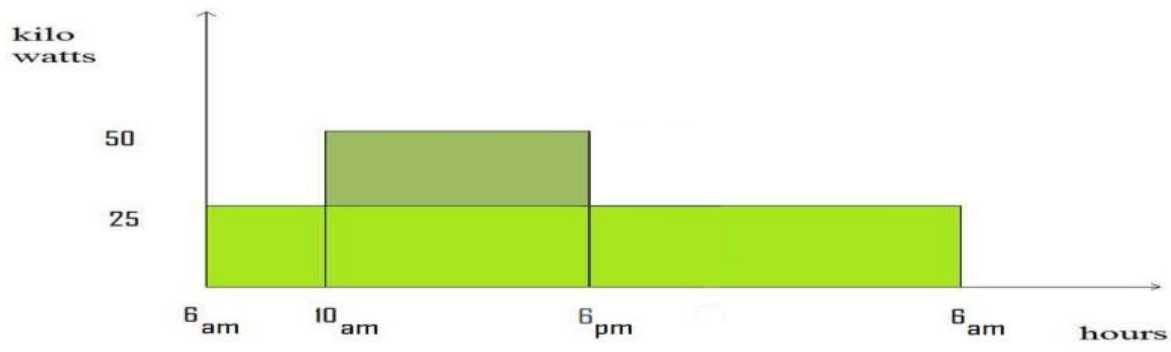

Fig.2. Load Curve

1. Total load supplied by Diesel system.

2. Total load supplied by PV-Diesel Battery System.

3. Base load supplied by DG.

4. Base load supplied by PV cells and Batteries.

5. Total load supplied by PV cells and Batteries.

6. Total load supplied by Wind -Diesel battery system

The results of the simulations are used to perform an economic analysis and predict the environmental impacts of integrating a PV array into diesel-electric power systems for remote villages. The economic part of the model calculates the fuel consumed, the kilowatt hours obtained per gallon of fuel supplied, and the total cost of fuel. It also calculates the $\mathrm{CO}_{2}$, particulate matter (PM), and the $\mathrm{NO}_{\mathrm{x}}$ emitted to the atmosphere [3-6]. 


\section{TOTAL LOAD SUPPLIEd BY DiESEL SYSTEM:}

In this system the 24 hours of load demand is fulfilled completely, only by the diesel generator. It is responsible for supplying both the peak and the average load of the system.

\section{TOTAL LOAD SUPPLied By PV DieSEl BATTERy SySTEM (PVDB):}

In this case we have divided the 24 hours of load in to two 12 hours sections in which the morning section that is from morning 6 A.M to evening 6 P.M is being supplied by diesel generator of $50 \mathrm{KW}$ rating (it is responsible for supplying both the peak and the average load of the system in its duration) and the night load from evening 6 P.M to morning 6 A.M is supplied by the battery of the required rating which charged with the help of photovoltaic cells from 8A.M to 5 P.M (considering constant solar insolation during this interval) supplies the night load. Ratings of the equipment's used are Diesel generator rating is $50 \mathrm{KW}$. Battery rating in $(\mathrm{KWh})$ the load that is to be supplied by battery for 12 hours from evening 6 P.M to morning 6A.M is constant load of 25KW as shown in Fig.2.

\section{BASE LOAD SUPPLIED BY DG}

In this case the base load of $25 \mathrm{~kW}$ of the system as shown in the load curve will be completely supplied by diesel generator for 24 hours and the peak load of $25 \mathrm{KW}$ from 10A.m to 6P.M i.e. 8 hours out of which 7 hours of load from 10am -5pm will be supplied by the PV cells directly (because of the limitation of the solar insolation after $5 \mathrm{pm}$ as considered), and the last one hour of peak load i.e. from $5 \mathrm{pm}$ to $6 \mathrm{pm}$ will be supplied by the battery which is charged in the morning hours before the occurrence of the peak load, through the PV cells. The load that is to be supplied by battery for 1 hour from $5 \mathrm{pm}$ to $6 \mathrm{pm}$ is constant load of $25 \mathrm{KW}$ as shown in Fig.2.

\section{BaSe LoAd SUPPLIED by PV Cells ANd BatTeries}

In this case the base load of $25 \mathrm{~kW}$ of the system as shown in the load curve will be completely supplied by Photo voltaic cells for 24 hours and the peak load of $25 \mathrm{KW}$ from 10A.m to 6P.M i.e. 8 hours is supplied by the diesel generator. Since here base load is completely supplied by the PV cells and the Batteries.

In this case the day time base load of $25 \mathrm{~kW}$ from $8 \mathrm{am}$ to $5 \mathrm{pm}$ is directly supplied from the PV cells and the remaining load $25 \mathrm{~kW}$ from $6 \mathrm{pm}$ to $8 \mathrm{am}$ are supplied from the batteries which are charged during the period $8 \mathrm{am}$ to $5 \mathrm{pm}$. The load that is to be supplied by battery for 14 hours from evening 6 P.M to morning $8 \mathrm{~A} . \mathrm{M}$ is constant load of $25 \mathrm{KW}$ as shown in Fig.2.

\section{TOTAL LOAD SUPPLIED BY PV CELLS AND BATTERIES:}

In this case we have divided the 24 hours of load in to two 12 hours sections in which the morning section that is from morning 6 A.M to evening 6 P.M is being supplied by diesel generator of 50KW rating (it is responsible for supplying both the peak and the average load of the system in its duration) and the night load from evening 6 P.M to morning 6 A.M is supplied by the battery of the required rating this charged with the help of wind energy from 8A.M to 5 P.M supplies the night load. Ratings of the equipment's used are Diesel generator rating is $50 \mathrm{KW}$. Battery rating in $(\mathrm{KWh})$ the load that is to be supplied by battery for 12 hours from evening 6 P.M to morning 6A.M is constant load of $25 \mathrm{KW}$ as shown in Fig.2.

In this system since the whole load is being supplied Photovoltaic cells and Batteries there is no need for diesel generator. Ratings of the equipment's used, Battery rating in $(\mathrm{KWh})$ the load that is to be supplied by battery for 14 hours from evening 6 P.M to morning 8A.M is constant load of $25 \mathrm{KW}$ as shown Fig.2.

\section{Total LOAd SUPPLIEd By Wind With DiESEl BATTERy SySTEM}

In this case we have divided the 24 hours of load in to two 12 hours sections in which the morning section that is from morning 6 A.M to evening 6 P.M is being supplied by diesel generator of 50KW rating (it is responsible for supplying both the peak and the average load of the system in its duration) and the night load from evening 6 P.M to morning 6 A.M is supplied by the battery of the required rating which charged with the help of wind energy from 8A.M to 5 P.M supplies the night load. Ratings of the equipment's used are Diesel generator rating is $50 \mathrm{KW}$. Battery rating in $(\mathrm{KWh})$ the load that is to be supplied by battery for 12 hours from evening 6 P.M to morning 6A.M is constant load of $25 \mathrm{KW}$ as shown in the load curve.

In this system since the whole load is being supplied Photovoltaic cells and Batteries there is no need for diesel generator. Ratings of the equipment's used, Battery rating in $(\mathrm{KWh})$ the load that is to be supplied by battery for 14 hours from evening 6 P.M to morning 8A.M is constant load of $25 \mathrm{KW}$ as shown in Fig.2. 


\section{Simulation RESUlts}

A model of an IPS was designed using MATLAB/Simulink to study the performance of the proposed power system. Simulink also allows the dynamic operation and the control system strategy to be incorporated into the IPS model to study the dynamic performance of the system. In this model the diesel generator is represented by the three phase source, The PV cells are represented by DC source, Battery is directly represented by the Li-Ion battery bank model, Wind Turbine represented by alternator.

The control operation of RTU is given with the help of Circuit Breakers (C.B) controlled by the pulse generator which switches on /off based on the pulses applied. As mentioned earlier we have divided the 24 hours of load in to two 12 hours sections in which the morning section that is from morning 6 A.M to evening 6 P.M is being supplied by diesel generator of $50 \mathrm{KW}$ rating (it is responsible for supplying both the peak and the average load of the system in its duration) and the night load from evening 6 P.M to morning 6 A.M is supplied by the battery of the required rating which charged with the help of photovoltaic cells from 8A.M to 5 P.M (considering constant solar insolation during this interval) supplies the night load.

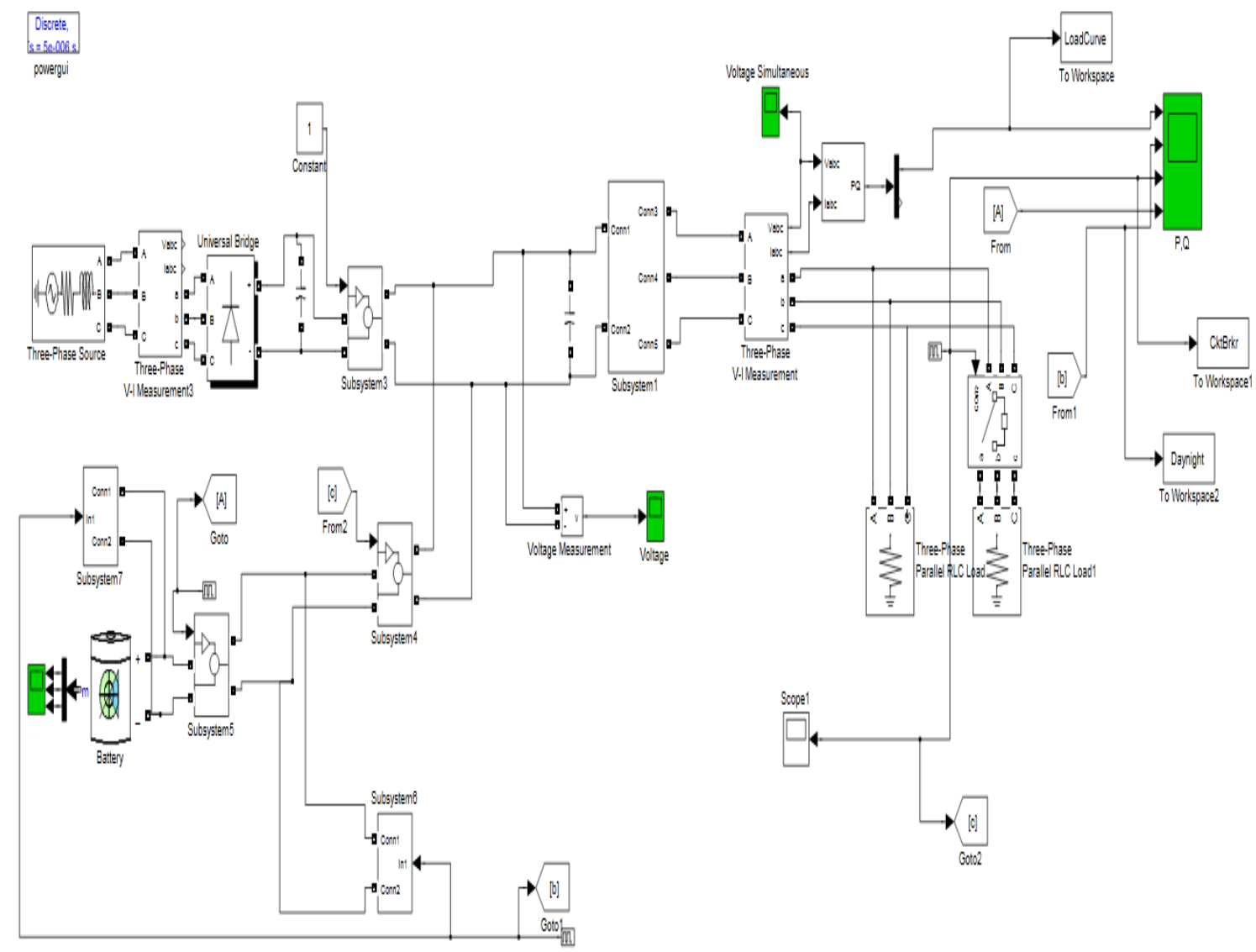

Fig.3. Simulink model of IPS system

Now the control of diesel generator is done with the help of C.B in subsystem 3 this C.B will be on from 6 A.M to 6 P.M since the pulses are given like that which can be seen in the output graph. Parallely during that period the batteries are getting charged by the PV cells which are controlled by the C.B in the subsystem7 and since both the operation i.e. DG supplying load and charging of the battery are done at a time so both are controlled by the same pulse generator.

Now during the time $6 \mathrm{pm}$ to $6 \mathrm{am}$ batteries are switched on by the C.Bs of subsystem 5 and 4 . The control of application of peak load of $25 \mathrm{~kW}$ is done with the help of pulse generator and the final output is seen across the scope "P,Q". The output of the above simulation is shown in Fig.5.As mentioned earlier the base load of $25 \mathrm{~kW}$ of the system as shown in the load curve will be completely supplied by diesel generator for 24 hours and the peak load of $25 \mathrm{~kW}$ from 10A.M to 6P.M i.e. 8 hours out of which 7 hours of load from 10 A.M - 5 P.M will be supplied by the PV cells directly (because of the limitation of the solar insolation after $5 \mathrm{pm}$ as considered), and the last one hour of peak load i.e. from 5 P.M to 6 P.M will be supplied by the battery which is charged in the morning hours before the occurrence of the peak load, through the PV cells. 


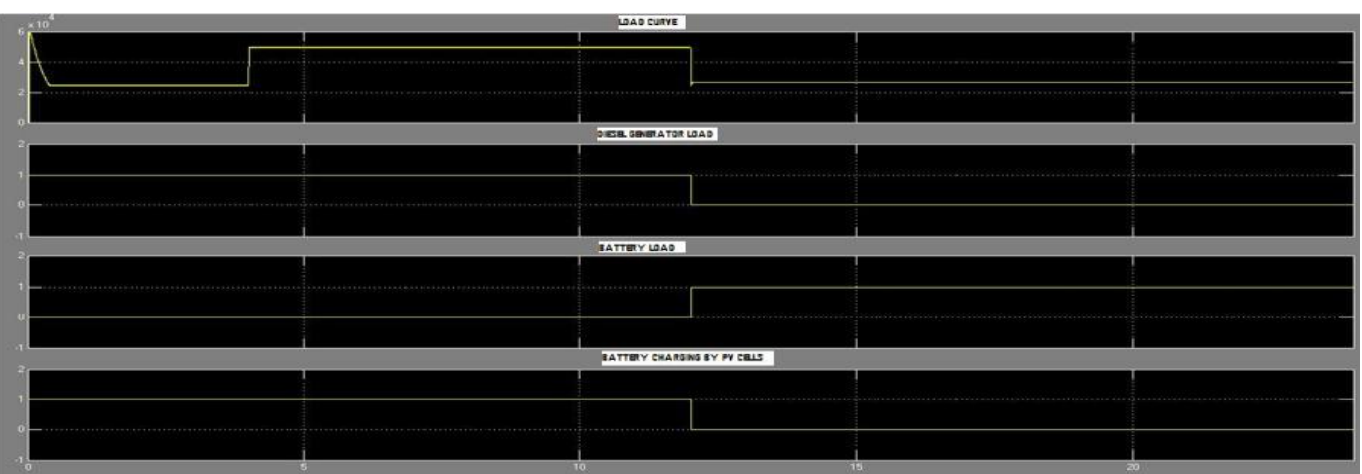

Fig. 4. Simulation results of PVDB system

Here the diesel generator will be on for 24 hours which is implemented by giving a constant pulse to C.B in the subsystem 3. and the peak load is applied by switching the C.B connected to the pulse generator. now during the peak load the power is supplied by the PV cells for 7 hours and battery for 1 hour is achieved by the control of C.Bs in the subsystem 4 and 5.The subsystem 4 is the common path for the powers from PV cells and the battery and its switching on and off should be at the same time as that of the peak load occurring time therefore same pulse generator should be applied at the peak load C.B and at the subsystem C.B.The final output is seen across the scope "P,Q". The output of the above simulation is shown in Fig.5.

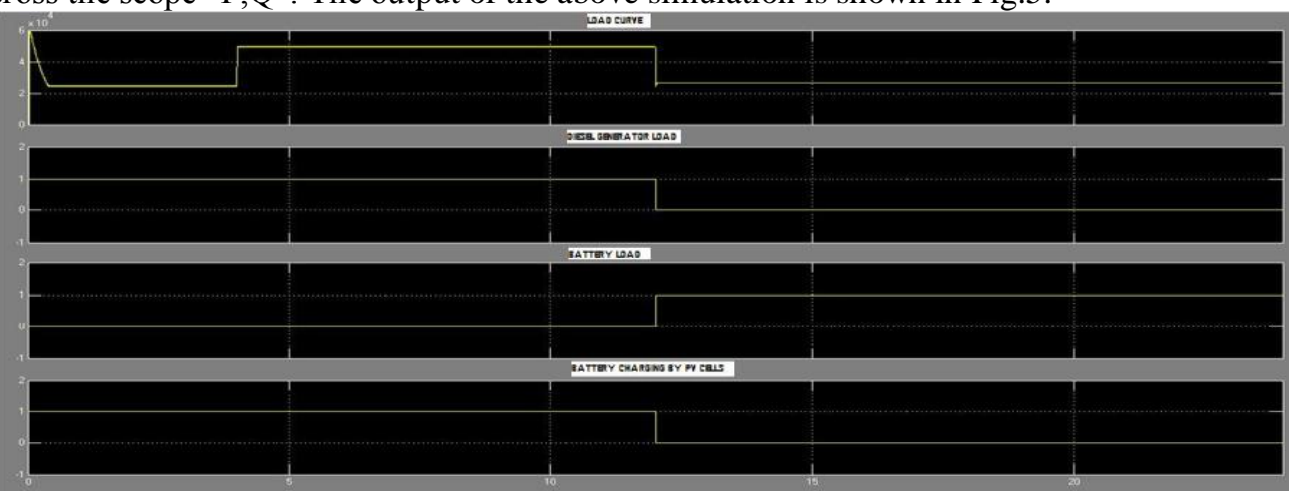

Fig.5. Simulation results of Base diesel system

In the case of PVDB system the day time base load of $25 \mathrm{~kW}$ from 8 A.M to 5 P.M is directly supplied from the PV cells and the remaining load 25kW from 6 P.M to 8 A.M are supplied from the batteries which are charged during the period 8 A.M to 5 P.M and the peak load is supplied with the help of diesel generator. Here the circuit breaker of subsystem 4 is on for 24 hours in order to supply the base load completely for 24 hours from PV cells and battery. The diesel generator should be on only during the peak load hours and hence the pulse generator controlling the peak load application and switching of diesel generator is same. The final output is seen across the scope "P,Q".

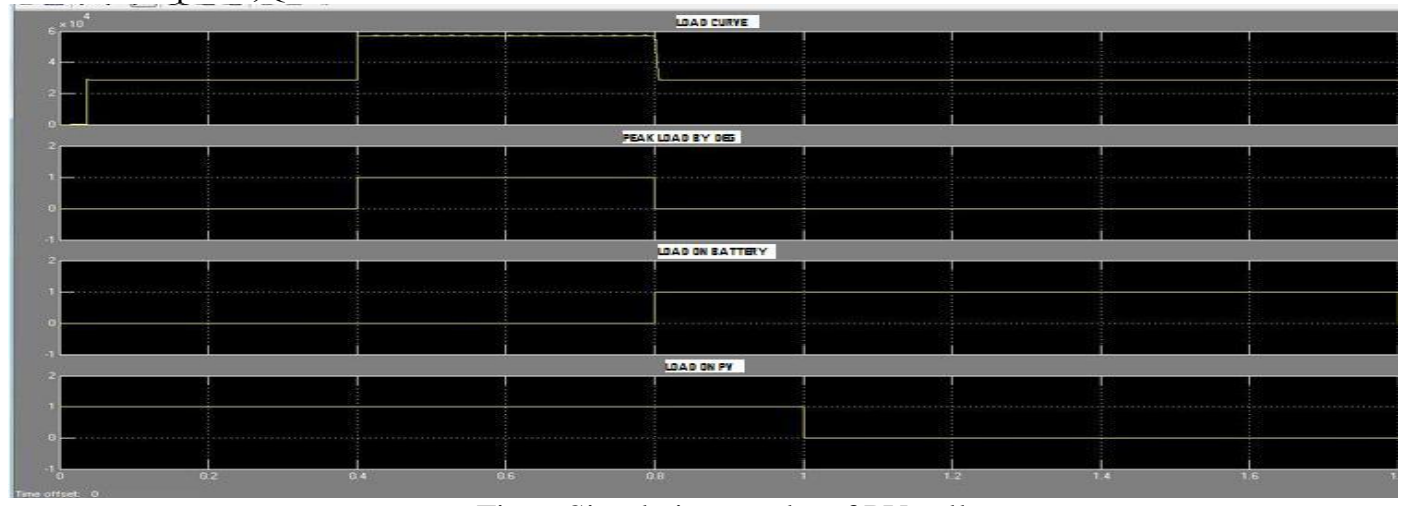

Fig.6. Simulation results of PV cells 


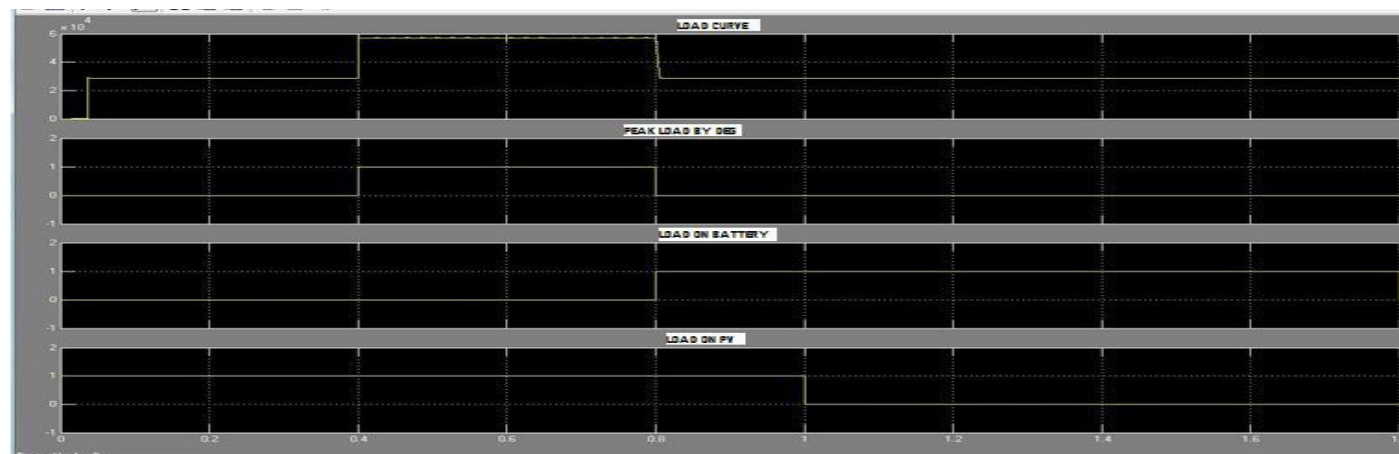

Fig.7. Simulation Results of complete load by PV Cells

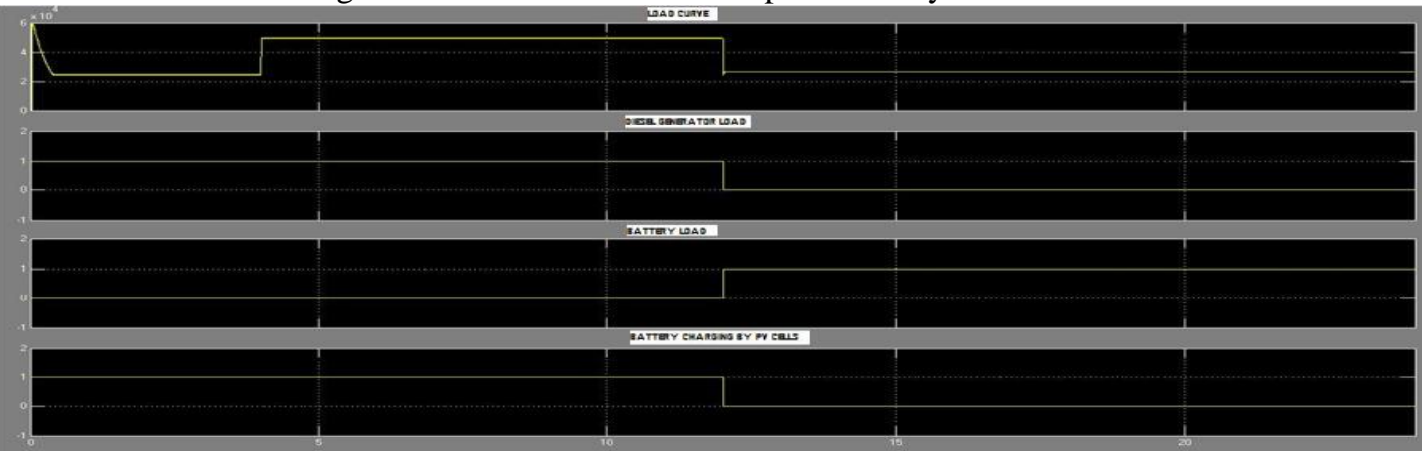

Fig.8. Output wave forms of Wind Diesel Battery system (WDB)

Thus as discussed in Section III cases the load sharing is done based on the availability and flexibility of different sources, the simulation results of Total load by PV cell, base load by PV cells and WDB system load sharing according to the load demand are shown in Fig.7. to Fig.9. The economic analysis of above designed APS is as follows

\section{ECONOMIC ANALYSIS:}

\section{TABLE-I}

\begin{tabular}{|c|l|c|c|c|}
\hline S.No & Equipment & Rating & $\begin{array}{c}\text { Cost/Unit in } \\
\text { Rupees }\end{array}$ & $\begin{array}{c}\text { Total Cost in } \\
\text { Rupees }\end{array}$ \\
\hline 1. & Diesel generator & $50 \mathrm{KW}$ & $5,00,000$ & $5,00,000$ \\
\hline 2. & Battery & $300 \mathrm{KWh}$ & 1152 & $3,45,600$ \\
\hline 3. & PV cells & $34 \mathrm{KW}$ & 120 & $40,80,000$ \\
\hline 4. & Wind & $50 \mathrm{KW}$ & $5,00,000$ & $5,00,000$ \\
\hline
\end{tabular}

- $\quad$ Diesel cost $-45 \mathrm{Rs} / \mathrm{lit}$.

- $\quad 3.1 \mathrm{~kg}$ of $\mathrm{CO}_{2}$ liberated for every combustion of $0.85 \mathrm{~kg}$ or $1.17 \mathrm{lit}$ of diesel.

- $8 \mathrm{gm}$ of $\mathrm{NO}_{\mathrm{x}}$ and PM are liberated for every 1 lit combustion of diesel.

- Compensation cost of $\mathrm{CO}_{2} 1.44 \mathrm{Rs} / \mathrm{kg}$ of $\mathrm{CO}_{2}$.

- Compensation cost of P.M\& $\mathrm{NO}_{\mathrm{x}}$ is $1.632 \mathrm{Rs} / \mathrm{gm}$.

- 4 litres of diesel is required to supply full load for an hour.

- Cost of PV cells 120Rs/watt.

- Cost of Lithium ion battery $1152 \mathrm{Rs} / \mathrm{kWh}$.

Note: The above values are taken from the IPCC (Inter Governmental Panel of Climate Change) \& Power theme Equipments (Pvt.) Ltd.

The economic analysis part of the simulation model involves calculation of the simple payback time (SPBT) for the proposed methods. In most of the remote villages, battery banks are used as back-up sources for power. Therefore, the PV with diesel-battery system is compared to the diesel-battery system in the analysis of SPBT. The SPBT is given as [7-9]

Simple Pay Back Time (SPBT):

In the case of PV system 


SPBT $=$ Additional cost for the PV cells, battery

In the case of Wind

$$
\text { SPBT }=\text { Additional cost for the Wind System }
$$

Savings per year

TABLE - II

Note: The above calculation are done based on the standard formulas referred from the previous papers[7-9].

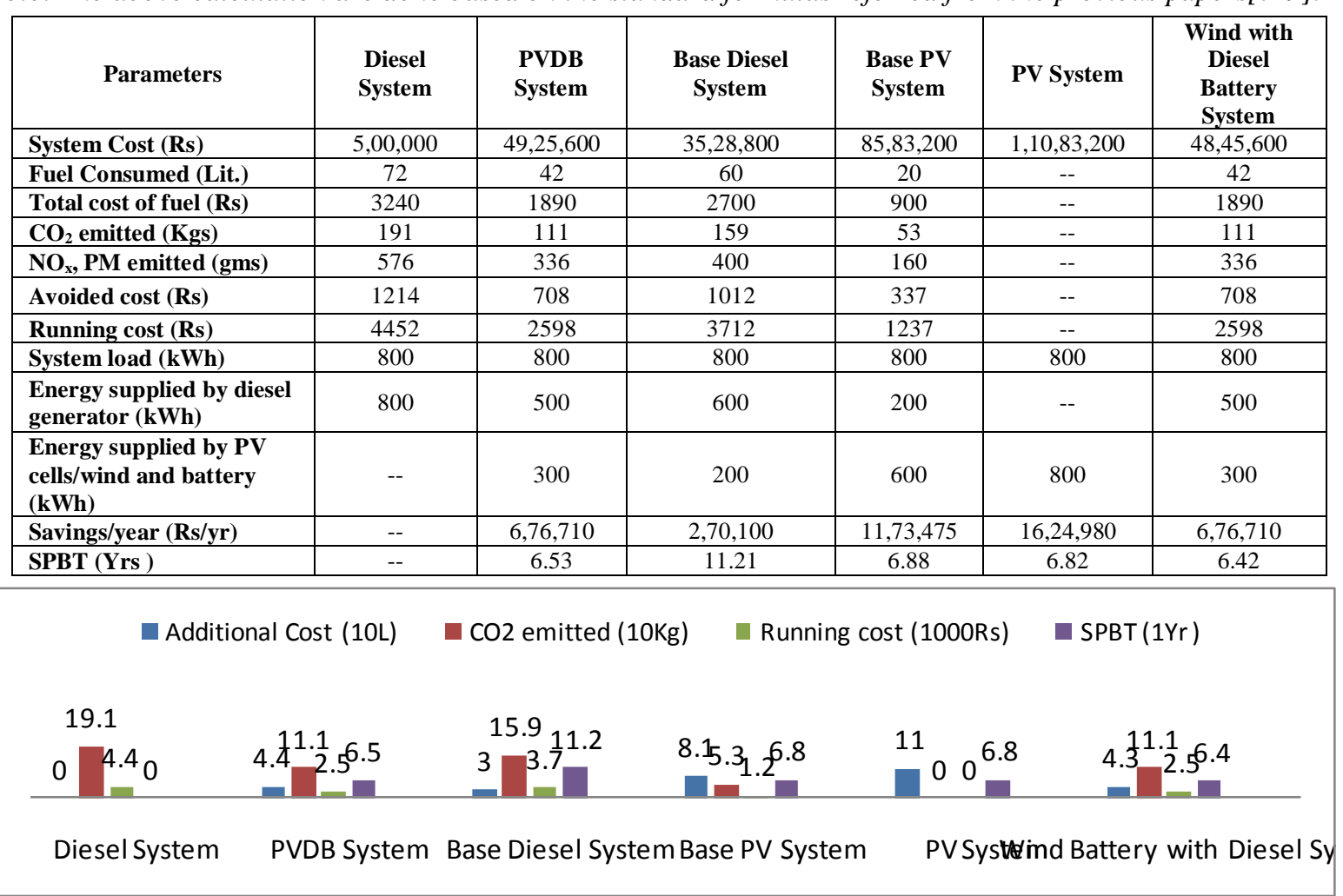

Fig.9.Comparison graph

Note: above calculated cost data is subjected to increase, costs are considered based on local available sources in Indian remote locations

\section{CONCLUSION}

The simulation results presented here highlights that the integration of a PV, Wind into a diesel-battery APS reduces the operating costs and the greenhouse gases and particulate matter emitted to the atmosphere by utilizing the RES based on load curve duration.

A Simulink model of independent power system for six different cases is developed in this paper to verify the distribution of load to RES based on availability of non conventional energy sources. With few modifications, the model can be extended to incorporate other renewable energy sources. The incorporation of additional renewable sources of energy, such as biomass, fuel cells, Husk power in this system, could further reduce fuel consumption. Hence by resolving to the non conventional means of generation, electricity can be economically provided to the remote location without harming environment.

\section{REFERENCES}

[1] Martin Kaltschmitt, Wolfgang Streicher, Andreas Wiese "Renewable Energy, Technology, Economics and Environment" published by Springer-Verlag Berlin Heidelberg 2007

[2] Jun-hai SHI, Zhi-dan ZHONG, Xin-jian ZHU, Guang-yi CAO "Robust design and optimization for autonomous PV-wind hybrid power systems" Journal of Zhejiang University SCIENCE ISSN 1673-565X (Print); ISSN 1862-1775 (Online) pp 401-409.

[3] O.C. Onar, M. Uzunoglu, and M.S. Alam, "Dynamic modelling, design and simulation of a wind/fuel cell/ultra-capacitor-based hybrid power generation system," Journal of Power Sources- ScienceDirect, vol. 161, pp. 707-722, 28th March 2006.

[4] Ahmed Agus Setiawan, Yu Zhao, Rob Susanto-Lee, and Chem. V. Nayar, "Design, economic analysis and environmental considerations of mini-grid hybrid power system with reverse Osmosis desalination plant for remote areas," Renewable EnergyElsevier, vol. 34, Iss.2, pp. 374-383, February 2009. 
[5] Dimitris Ipsakis, Garyfallos Giannakoudis, Athanasios I. Papadopoulos, Spyros Voutetakis, Panos Seferlis "Design And Optimization of A Stand-Alone Power System Based On Renewable Energy Sources" Power Management Strategies in a StandAlone Power System, Energy 33, pp. 1537-1550, 2008.

[6] Arzu Sencan Sahin "Modelling and Optimization of Renewable Energy Systems" published by InTech Janeza Trdine 9, 51000 Rijeka, Croatia.

[7] Pavlos S. Georgilakis, Yiannis A. Katsigiannis "Reliability and economic evaluation of small autonomous power systems containing only renewable energy sources" Renewable Energy Journal 34 (2009) pp. 65-70.

[8] Ashish N. Agrawal, Richard W. Wies, Ronald A. Johnson "Development of a Simulink Model to Study the Sensitivity Analysis of Fuel Cost on Wind with Diesel-Battery Hybrid Power Systems for Remote Locations" project by the Arctic Energy Technology Development Laboratory (AETDL) at the University of Alaska Fairbanks

[9] Shafiqur Rehman, Luai M. Al-Hadhrami "Study of a solar PV- dieselel battery hybrid power system for a remotely located population near Rafha, Saudi Arabia” Energy Journal 35 (2010) pp.4986-4995. 